\title{
Impact of Scientific Dairy Farming Trainings on Farmers Knowledge about Management Practices
}

\author{
Monika Sharma $^{1 *}$, S. S. Sangwan ${ }^{1}$, Rakesh Ahuja $^{1}$ and Ramkaran ${ }^{2}$ \\ ${ }^{1}$ Department of Veterinary and Animal Husbandry Extension Education, ${ }^{2}$ Department of \\ Veterinary Biochemistry, College of Veterinary Sciences, LalaLajpat Rai University of \\ Veterinary and Animal Sciences, Hisar-(Haryana), India \\ *Corresponding author
}

A B S T R A C T

\begin{tabular}{l} 
Key w o r d s \\
Knowledge, \\
Management \\
practices, Training, \\
Participants and \\
Haryana \\
\hline Article Info \\
$\begin{array}{l}\text { Accepted: } \\
15 \text { April } 2020 \\
\text { Available Online: } \\
10 \text { May } 2020\end{array}$ \\
\hline
\end{tabular}

A study in Hisar district of Haryana was conducted during 2014-15 to assess the impact of scientific dairy farming training on knowledge level of dairy farmers about management practices on randomly selected 60 participant and 60 non-participant respondents. Data were collected through personal interview with the help of pretested structured interview schedule from two villages during 2014-15. The study reveals that majority $(53.33 \%)$ of participant and non-participant dairy farmers had medium level of knowledge about management practices of scientific dairy husbandry practices. However, the participant farmers had higher knowledge of management practices in comparison to non-participants. All the participant and non-participant farmers knew about height of animal shed and Veterinarian's help during difficult calving (100\%) followed by 'best type of housing for rearing', 'time of deworming', 'stop milking before next parturition', 'cleanliness of animal shed' and 'correct method of milking'. The respondents were least know about weaning practice, removal of naval cord and age of castration of calf were least known. Farming experience was found to have negative and significant correlation with knowledge about management practices at 5 per cent level of significance while extension contact, economic motivation, attitude toward dairy farming and market orientation were found to have positive and significant correlation with knowledge of farmers at 1 per cent level of significance.

\section{Introduction}

India is the largest milk producer in the world; therefore role of dairy farmers is very important in dairy industry and socioeconomic development of the society (Chaudhari et al., 2007). From the beginning of the 20th century the Indian livestock industry has attracted widespread attention and benefited from multiple organized development programs. The pace of dairy development for example rapidly accelerated after 1970, fuelled by Operation Flood.

Subsequently, dairy development was seen as a nationwide antipoverty instrument with huge potential to ensure greater equity and food and social security in rural India. 
Designing a suitable extension strategy to improve milk productivity requires a thorough understanding of existing level of knowledge of farmers. Knowledge level of farmers may be increased by conducting trainings for dairy farmers on the latest dairy farming practices. Knowledge of scientific practices and its adoption may enhance the productivity of animals. Singh et al., (2011) concluded that overall 79.07 per cent increase in knowledge level of dairy farmers was observed as a result of dairy farming training. Yadav and Pareek (2014) reported that majority of the oncampus trainee's use of animal husbandry practices had high level of knowledge. The Directorate of Extension Education, LUVAS regularly organizes trainings for rural youth for Scientific Dairy Farming. Therefore, it is essential to assess the impact of these trainings. Keeping the above facts in view, a study was carried out to assess the impact of scientific dairy farming trainings on the knowledge level of participants about management practices.

\section{Materials and Methods}

The study was conducted in Hisar district of Haryana state keeping in view the fact that on-campus trainings on scientific dairy farming are organized at LUVAS, Hisar regularly. A list of farmers who participated in such trainings was obtained from the Directorate of Extension Education. The list consists of farmers from Hisar, Fatehabad and Bhiwani districts. Hisar district was selected randomly. From Hisar district village Gorchi was selected purposively as more than 80 farmers figured in list from a single village for scientific dairy farming trainings. Out of those 60 respondents were selected randomly. Similarly nonparticipant farmers as control group were selected from neighbouring i.e. Panihar village. Sixty farmers were selected from each of the two selected villages thus constituting a sample size of 120 dairy farmers. The relevant independent variables included in this study were age, educational qualification, land holding, total income, caste, farming experience, herd size, extension contact, social participation, mass media exposure, economic motivation, scientific orientation, attitude towards dairy farming and market orientation. A structured interview schedule was prepared on the basis of improved package of practices and expert opinions of the scientists. A knowledge test comprising of 13 major recommended management practices of dairy animals was developed to measure the knowledge level of the respondents.

The data were collected through personal interview during 2014-15. The responses of dairy farmers were obtained on three point continuums i.e. correct, partially correct and wrong answer and score of 3,2 and 1 was allotted, respectively. On the basis of knowledge score, dairy farmers were then grouped into three categories viz., low, medium and high level of knowledge using the mean and standard deviation formula.

\section{Results and Discussion}

\section{Knowledge level regarding management practices}

A perusal of the data (Table-1) reveals that about half $(55.00 \%)$ of the participant farmers had medium level of knowledge about management practices followed by high $(26.67 \%)$ and low $(18.33 \%)$ in management aspect respectively.

However, in case of non-participant category of farmers, 51.67 per cent of them possessed medium level of knowledge followed by 34.61 and 28.20 per cent who had high and low knowledge about management practices, respectively. Overall, it reveals that 53.33 per cent of the respondents had medium level of 
knowledge regarding management practices and hence knowing as how to manage their dairy farms based on scientific knowledge while 25.84 and 20.83 per cent were found to have high and low level of knowledge, respectively. This observation may be attributed to their herd size, medium level of income, medium educational qualification and economic motivation. The ' $Z$ ' value of management practices was found significant which indicates that the participant had higher knowledge than non-participants groups. This significant difference clearly reveals the impact of training on farmers knowledge. These findings are in line with findings of Deepak (2004), Manivannani et al., (2008), Kumar et al., (2011) and Aulakh et al., (2011).

\section{Item wise knowledge level of dairy farmers about management practices}

Data in the Table 2 further reveals that farmers of participant category possessed excellent knowledge about 'height of animal shed' and Veterinarian's help during difficult calving' to the extent of 100 per cent and hence ranked first. It was followed by the item 'best type of housing for rearing' (95.67\%), time of deworming (90\%), stop milking before next parturition (87.67\%), cleanliness of animal shed (87.67\%) and correct method of milking (87.67\%). Knowledge about 'weaning practice' $(43.33 \%)$ and 'age of castration of calf' $(42.33 \%)$ were least known areas and ranked ninth and tenth position accordingly. In case of non-participant category of farmers, almost similar results were reported. Knowledge about removal of naval cord $(43.33 \%)$ and weaning practice $(35.67 \%)$ were found lowest. The overall analysis reveals that all the farmers of both groups knew about 'height of animal shed' as evident from their mean per cent score $(100 \%)$. Moreover 99 per cent of them were taken help from veterinarians during calving followed by 'best type of housing for rearing' $(89.33 \%)$. The plausible reason for higher knowledge of these practices could be that, these practices did not require special efforts and skills on the part of the dairy farmers and also are the basic and minimum practices necessary to be carried out in the farm on routine basis for attaining successful profit. Poor knowledge may be due to lesser practice or utilization. Sharma et al., (2009) also observed that the farmers had higher knowledge about 'cleanliness of buffalo shed' and 'height of buffalo shed' while poor knowledge was recorded about 'disinfestation of shed before calving' among all management practices.

\section{Correlation and regression coefficients between personal attributes and knowledge of dairy farmers about management practices}

It is clear from the data (Table 3) that among the participant farmers, economic motivation $(r=0.259)$ had positive and significant correlation with knowledge level about management practices at 5 per cent level of significance. With respect to the nonparticipant dairy farmers, herd size $(\mathrm{r}=0.263)$ and attitude towards dairy farming $(\mathrm{r}=0.277)$ were found to have positive and significant correlation at 5 per cent level of significance.

Overall, among all the 14 independent variables, scientific orientation $(r=0.212)$ was positive and farming experience $(\mathrm{r}=-0.221)$ was found to have negative and significant correlation with knowledge about management practices at 5 per cent level of significance. This indicates that with the increase in farming experience there is a decrease in knowledge. Farmers who have been long in the profession are usually older, less educated and are reluctant to change than the new entrants which hinders in acquisition of more knowledge. 
Table.1 Level of knowledge of dairy farmers about management practices

\begin{tabular}{|c|c|c|c|c|c|c|}
\hline \multirow[t]{2}{*}{$\begin{array}{l}\text { S. } \\
\text { No. }\end{array}$} & \multirow[t]{2}{*}{ Aspects } & \multirow[t]{2}{*}{ Category } & Participants & $\begin{array}{c}\text { Non- } \\
\text { participants }\end{array}$ & Total & \multirow[t]{2}{*}{$\begin{array}{c}\text { 'Z' } \\
\text { Value }\end{array}$} \\
\hline & & & F (\%) & $\mathbf{F}(\%)$ & $\mathbf{F}(\%)$ & \\
\hline \multirow[t]{4}{*}{1.} & \multirow[t]{4}{*}{ Management } & Low & $11(18.33 \%)$ & $14(23.33 \%)$ & $25(20.83 \%)$ & \multirow[t]{4}{*}{$6.28 * *$} \\
\hline & & Medium & $33(55.00 \%)$ & $31(51.67 \%)$ & $64(53.33 \%)$ & \\
\hline & & High & $16(26.67 \%)$ & $15(25.00 \%)$ & $31(25.84 \%)$ & \\
\hline & & $\begin{array}{l}\text { Mean } \\
\text { SD }\end{array}$ & $\begin{array}{c}24.97 \\
3.16\end{array}$ & $\begin{array}{c}21.53 \\
2.84\end{array}$ & $\begin{array}{c}23.25 \\
3.46\end{array}$ & \\
\hline
\end{tabular}

Table.2 Item wise knowledge level of dairy farmers about management practices

\begin{tabular}{|c|c|c|c|c|c|c|c|c|c|c|}
\hline \multirow{2}{*}{$\begin{array}{l}\text { S. } \\
\text { No. }\end{array}$} & \multirow[t]{2}{*}{ Item } & \multicolumn{3}{|c|}{ Participants } & \multicolumn{3}{|c|}{ Non-participants } & \multicolumn{3}{|c|}{ Total } \\
\hline & & MS & MPS & Rank & MS & MPS & Rank & MS & MPS & Rank \\
\hline 1 & $\begin{array}{l}\text { Cleanliness of } \\
\text { animal shed }\end{array}$ & 2.63 & 87.67 & IV & 2.50 & 83.33 & III & 2.57 & 85.67 & IV \\
\hline 2 & $\begin{array}{l}\text { Height of animal } \\
\text { shed }\end{array}$ & 3.00 & 100.00 & I & 3.00 & 100.00 & I & 3.00 & 100.00 & I \\
\hline 3 & $\begin{array}{l}\text { Best type of } \\
\text { housing for rearing }\end{array}$ & 2.87 & 95.67 & II & 2.50 & 83.33 & III & 2.68 & 89.33 & III \\
\hline 4 & $\begin{array}{l}\text { Stop milking before } \\
\text { next parturition }\end{array}$ & 2.63 & 87.67 & IV & 2.45 & 81.67 & IV & 2.54 & 84.67 & V \\
\hline 5 & $\begin{array}{l}\text { Disinfection of } \\
\text { animal shed before } \\
\text { calving }\end{array}$ & 2.33 & 77.67 & VI & 1.47 & 49.00 & VIII & 1.90 & 63.33 & VIII \\
\hline 6 & $\begin{array}{l}\text { Veterinarian's help } \\
\text { during difficult } \\
\text { calving }\end{array}$ & 3.00 & 100.00 & I & 2.93 & 97.67 & II & 2.97 & 99.00 & II \\
\hline 7 & $\begin{array}{l}\text { Removal of } \\
\text { placenta }\end{array}$ & 2.42 & 80.67 & $\mathrm{~V}$ & 2.40 & 80.00 & $\mathrm{~V}$ & 2.41 & 80.33 & VII \\
\hline 8 & $\begin{array}{l}\text { Precautions after } \\
\text { expulsion of } \\
\text { placenta }\end{array}$ & 2.00 & 66.67 & VII & 1.43 & 47.67 & IX & 1.72 & 57.33 & IX \\
\hline 9 & $\begin{array}{l}\text { Removal of naval } \\
\text { cord }\end{array}$ & 1.80 & 60.00 & VIII & 1.30 & 43.33 & $\mathrm{X}$ & 1.55 & 51.67 & $\mathrm{X}$ \\
\hline 10 & Weaning practice & 1.30 & 43.33 & IX & 1.07 & 35.67 & XI & 1.18 & 39.33 & XII \\
\hline 11 & $\begin{array}{l}\text { Age of castration of } \\
\text { calf }\end{array}$ & 1.27 & 42.33 & $X$ & 1.50 & 50.00 & VII & 1.38 & 46.00 & XI \\
\hline 12 & $\begin{array}{l}\text { Time of } \\
\text { Deworming }\end{array}$ & 2.70 & 90.00 & III & 2.20 & 73.33 & VI & 2.45 & 81.67 & VI \\
\hline 13 & $\begin{array}{l}\text { Correct method of } \\
\text { milking }\end{array}$ & 2.63 & 87.67 & IV & 2.50 & 83.33 & III & 2.57 & 85.67 & IV \\
\hline
\end{tabular}


Table.3 Correlation and regression coefficients between personal attributes and knowledge level about management practices

\begin{tabular}{|c|c|c|c|c|c|c|c|}
\hline \multirow{2}{*}{$\begin{array}{l}\text { S. } \\
\text { No. }\end{array}$} & \multirow{2}{*}{$\begin{array}{l}\text { Independent } \\
\text { Variables }\end{array}$} & \multicolumn{2}{|c|}{ Participants } & \multicolumn{2}{|c|}{ Non-participants } & \multicolumn{2}{|c|}{ Overall } \\
\hline & & 'r' & 'b' & 'r' & 'b' & 'r' & 'b' \\
\hline 1 & $\operatorname{Age}\left(\mathrm{X}_{1}\right)$ & -0.015 & 0.084 & 0.046 & 0.229 & -0.132 & 0.144 \\
\hline 2 & Education $\left(\mathrm{X}_{2}\right)$ & 0.151 & 0.178 & -0.059 & -0.566 & 0.070 & -0.161 \\
\hline 3 & Land holding $\left(\mathrm{X}_{3}\right)$ & 0.141 & 0.391 & 0.237 & 0.632 & 0.103 & 0.234 \\
\hline 4 & Total income $\left(\mathrm{X}_{4}\right)$ & 0.086 & -0.001 & 0.192 & 0.003 & 0.058 & 0.0004 \\
\hline 5 & $\operatorname{Caste}\left(\mathrm{X}_{5}\right)$ & 0.153 & 1.002 & 0.135 & -0.467 & 0.084 & 0.478 \\
\hline 6 & $\begin{array}{l}\text { Farming } \\
\text { experience }\left(\mathrm{X}_{6}\right)\end{array}$ & -0.132 & -0.092 & -0.031 & -0.273 & $-0.221 *$ & -0.190 \\
\hline 7 & Herd $\operatorname{size}\left(X_{7}\right)$ & -0.058 & 0.234 & $0.263^{*}$ & 0.980 & 0.127 & 0.683 \\
\hline 8 & $\begin{array}{l}\text { Extension } \\
\operatorname{contact}\left(\mathrm{X}_{8}\right)\end{array}$ & -0.091 & -0.413 & 0.137 & 0.124 & $0.239 * *$ & 0.255 \\
\hline 9 & $\begin{array}{l}\text { Social } \\
\text { participation }\left(X_{9}\right)\end{array}$ & 0.051 & 0.651 & 0.094 & 0.198 & 0.054 & 0.314 \\
\hline 10 & $\begin{array}{l}\text { Mass media } \\
\text { exposure }\left(\mathrm{X}_{10}\right)\end{array}$ & -0.013 & -0.072 & -0.101 & -0.133 & 0.069 & -0.214 \\
\hline 11 & $\begin{array}{l}\text { Economic } \\
\text { motivation }\left(\mathrm{X}_{11}\right)\end{array}$ & $0.259^{*}$ & 0.300 & 0.213 & 0.322 & $0.380^{* *}$ & 0.379 \\
\hline 12 & $\begin{array}{l}\text { Scientific } \\
\text { orientation }\left(\mathrm{X}_{12}\right)\end{array}$ & 0.160 & -0.006 & 0.101 & -0.129 & $0.212^{*}$ & -0.112 \\
\hline 13 & $\begin{array}{l}\text { Attitude towards } \\
\text { dairy farming }\left(\mathrm{X}_{13}\right)\end{array}$ & -0.014 & -0.161 & $0.277 *$ & 0.479 & $0.329 * *$ & 0.287 \\
\hline 14 & $\begin{array}{l}\text { Market } \\
\text { orientation }\left(\mathrm{X}_{14}\right)\end{array}$ & 0.064 & -0.007 & 0.183 & -0.053 & $0.261 * *$ & 0.138 \\
\hline & $\mathrm{R}^{2}$ & & 0.179 & & 0.383 & & 0.299 \\
\hline & $\mathrm{F}$ & & 0.700 & & $1.997 *$ & & $3.192 * *$ \\
\hline
\end{tabular}

*Significant at $5 \%$ level of probability** Significant at $1 \%$ level of probability

The present findings contradict with the findings of Rahelizatovo et al., (2004), Sandeep et al., (2006), Halakatti et al., (2007), Hasan et al., (2008), Nchinda and Mendi (2008) and Sharma et al., (2009) who found farming experience was negatively correlated with knowledge.

Extension contact $(r=0.239)$, economic motivation $(r=0.380)$, attitude toward dairy farming $(\mathrm{r}=0.329)$ and market orientation $(\mathrm{r}=$ 0.261 ) were found to have positive and significant correlation with knowledge of farmers at 1 per cent level of significance.
More extension contact hereby means more exposure to the various information and interactions with various crucial and critical informants of dairy farming and hence, it may have attributed to the gain in knowledge. Arora et al., (2006), Sharma and Singh (2008), Meena et al., (2009) and Sharma et al., (2009) also reported positive and highly significant relationship of extension contact with knowledge level of dairy farmers. Among the participant and non-participant dairy farmers not a single variable was found to have significant ' $b$ ' value. In overall analysis of dairy farmers the variables 
namely, attitude toward dairy farming and economic motivation were found to have highly significant ' $b$ ' value while farming experience had negative and significant value of ' $b$ '. These findings are in agreement with the findings of Arora et al., (2006), Halakatti et al., (2007) and Fita et al., (2012).

It can be concluded that there is difference in the knowledge level of participant and nonparticipant dairy farmers in management as the ' $Z$ ' value was found significant. There are certain areas of dairy farming where knowledge level was poor and trainings need to improve that part. Hence it would need actions on the part of administrators, scientists, farmers and all those who have a concern for better prospects of dairy farming.

\section{Acknowledgement}

We are very thankful to the Head, Department of Veterinary and Animal Husbandry Extension Education of Lala Lajpat Rai University of Veterinary and Animal Sciences for providing the facilities to conduct this study.

\section{References}

Arora, A.S., Kumar, A., Bardhan, D. and Dabas, Y.P.S. (2006). Adoption of improved animal husbandry practices as risk management strategies. Indian journal of Extension Education. 42 (3 \& 4): 41-46.

Aulakh, G.S., Yadav, J.S. and Singh, R. (2011). Knowledge level of dairy farmers regarding recommended buffalo management practices. J. Dairying, Foods \& H.S. 30 (2): 147 - 149.

Chaudhari, R.R., Hirevenkanagoudar, V., Hanchinal, S.N., Mokashi, A.N., Katharki, P.A. and Banakar, B. (2007). A scale for measurement of entrepreneurial behavior of dairy farmers. Karnataka J. Agric. Sci. 20 (4): 792-796.

Deepak, K. (2004). Training needs of rural women in buffalo rearing practices. M.Sc. Thesis, CCS, Haryana Agricultural University, Hisar.

Fita, L., Trivedi, M.M. and Tassew, B. (2012). Adoption of improved dairy husbandry practices and its relationship with the socio-economic characteristics of dairy farmers in Ada'a district of Oromia State, Ethiopia. Journal of Agricultural Extension and Rural Development. 4 (14): 392-395.

Halakatti, S.V., Vijayalaxmi, K. and Gowda, D.S. (2007). Determinants of adoption of dairy farming technologies by rural women under SGSY scheme, Karnataka. J. Agric. Sci. 20 (2): 323325.

Hasan, C., Yavuz, C. and Murat, T. (2008). Socio-economic factors affecting the level of adoption of innovations in dairy cattle enterprises. Ankara Univ. Vet. Faculty. 55:183-187.

Kumar, S., Kumar, B., Hindustani, S. and Sankhala, G. (2011). Knowledge level of dairy farmers in operational area of Krishi Vigyan Kendra about improved dairy farming practices. Research Journal of Agricultural Sciences. 2 (1): 122-124.

Manivannan, A.N., Narmath and Uma, V. (2008). Knowledge level of dairy farmers on calf rearing practices. $J$. Ext. Edu. 20 (1-4): 4131-4133.

Meena, B.S., Singh, A.K., Chauhan, J. and Sankhala, G. (2009). Farmers' knowledge on feeding practices of dairy animals in Jhansi District. Indian Res. J. Ext. Edu. 9 (1): 28-31.

Nchinda, V.P., Mendi, S.D. (2008). Factors influencing the adoption of yoghurt technology in the Western Highlands Agro-ecological zone of Cameroon. Livest. Res. Rural Dev. 20 (7):320-328. 
Rahelizatovo, N., Gillespie, C. and Jeffrey, M. (2004). Adoption of best management practices by Louisiana dairy producers. J. Agric. Appl. Econ. 14 (6): 312-321.

Sandeep, J., Malik, S. and Singh, S.D. (2006). Comparative adoption level of farmers regarding improved animal husbandry practices in watershed and nonwatershed villages. J. Dairying. Foods Home. Sci. 25 (1):51-54.

Sharma, K., Singh, S.P., Yadav, V.P.S. (2009). Knowledge of dairy farmers about improved buffalo husbandry practices. Indian Res. J. Extn. Edn. 9
(3):51-54.

Sharma, K. and Singh, S.P. (2008). Dairy farmers knowledge about buffalo feeding practices. Haryana Veterinarian. 47: 68-71.

Singh, S., Kumar, R., Sharma, C.S., Kumar, U. and Kumar, A. (2011). Improved dairy production and processing through training programmes. J. Dairying, Foods \& H.S. 30 (3): 165-169.

Yadav, C.M. and Pareek, O.P. (2014). Impact of on campus training on knowledge empowerment of trainees in Bhilwara district of Rajasthan. Indian Res. J. Ext. Edu. 14 (1).

\section{How to cite this article:}

Monika Sharma, S. S. Sangwan, Rakesh Ahuja and Ramkaran. 2020. Impact of Scientific Dairy Farming Trainings on Farmers Knowledge about Management Practices. Int.J.Curr.Microbiol.App.Sci. 9(05): 1746-1752. doi: https://doi.org/10.20546/ijcmas.2020.905.196 